\title{
IDENTIFICATION OF THE BACTERIAL COMMUNITY RESPONSIBLE FOR TRADITIONAL FERMENTATION DURING SOUR CASSAVA STARCH, CACHAÇA AND MINAS CHEESE PRODUCTION USING CULTURE- INDEPENDENT 16S rRNA GENE SEQUENCE ANALYSIS
}

\author{
Inayara C. A. Lacerda ${ }^{1}$, Fátima C. O. Gomes ${ }^{2}$, Beatriz M. Borelli ${ }^{3}$, César L. L. Faria Jr. ${ }^{3}$, Gloria R. Franco ${ }^{4}$, Marina M. \\ Mourão ${ }^{4}$, Paula B. Morais ${ }^{5}$, Carlos A. Rosa ${ }^{3 *}$
}

${ }^{1}$ Departamento de Alimentos, Faculdade de Farmácia, Universidade Federal de Minas Gerais, Belo Horizonte, MG, Brasil;

${ }^{2}$ Departamento de Química, Centro Federal de Educação Tecnológica, Belo Horizonte, MG, Brasil; ${ }^{3}$ Departamento de Microbiologia, Instituto de Ciências Biomédicas, Universidade Federal de Minas Gerais, Belo Horizonte, MG, Brasil;

${ }^{4}$ Departamento de Bioquímica, Instituto de Ciências Biomédicas, Universidade Federal de Minas Gerais, Belo Horizonte, MG, Brasil; ${ }^{5}$ Laboratório de Microbiologia Ambiental e Biologia, Campus Universitário de Palmas, Fundação Universidade Federal do Tocantins, Palmas, TO, Brasil.

Submitted: January 08, 2010; Returned to authors for corrections: November 17, 2010; Approved: January $13,2011$.

\begin{abstract}
We used a cultivation-independent, clone library-based 16S rRNA gene sequence analysis to identify bacterial communities present during traditional fermentation in sour cassava starch, cachaça and cheese production in Brazil. Partial 16S rRNA gene clone sequences from sour cassava starch samples collected on day five of the fermentation process indicated that Leuconostoc citreum was the most prevalent species, representing $47.6 \%$ of the clones. After 27 days of fermentation, clones (GenBank accession numbers GQ999786 and GQ999788) related to unculturable bacteria were the most prevalent, representing 43.8\% of the clones from the bacterial community analyzed. The clone represented by the sequence GQ999786 was the most prevalent at the end of the fermentation period. The majority of clones obtained from cachaça samples during the fermentation of sugar cane juice were from the genus Lactobacillus. Lactobacillus nagelli was the most prevalent at the beginning of the fermentation process, representing $76.9 \%$ of the clones analyzed. After 21 days, Lactobacillus harbinensis was the most prevalent species, representing 75\% of the total clones. At the end of the fermentation period, Lactobacillus buchneri was the most prevalent species, representing $57.9 \%$ of the total clones. In the Minas cheese samples, Lactococcus lactis was the most prevalent species after seven days of ripening. After 60 days of ripening, Streptococcus salivarius was the most prevalent species. Our data show that these three fermentation processes are conducted by a succession of bacterial species, of which lactic acid bacteria are the most prevalent.
\end{abstract}

Key words: fermentation, cassava, cachaça, cheese, clone library

*Corresponding Author. Mailing address: Departamento de Microbiologia, ICB, C. P. 486, Universidade Federal de Minas Gerais, Belo Horizonte, 31270-901, Brazil.; Fax: 5531 34092751.; E-mail: carlrosa@icb.ufmg.br 


\section{INTRODUCTION}

Culture-based methods are not designed to detect unculturable cells and often fail to characterize less abundant microbial populations or those microorganisms that require selective enrichment (17). These limitations have led to the development of culture-independent techniques. The most commonly used techniques are PCR-based and nucleic acidbased detection methods (28). Compared to conventional methods, culture-independent methods are generally less time consuming and well suited for analyzing microbial communities over time. These methods may also help in the study of microbial populations and their diversity in food ecosystems (16).

Sour cassava starch ("polvilho azedo") and Minas cheese are traditional fermented foods produced in Brazil. These products are mostly manufactured on a small scale using traditional recipes $(5,18)$. During sour cassava starch production, the starch from cassava root is fermented in a tank for a period of time that ranges between 20 and 70 days $(7,18)$. Using culture-based methods, Lactobacillus plantarum and other lactic acid bacteria have been reported to be the most prevalent microorganisms associated with spontaneous fermentation of cassava starch in Brazil (18). These microorganisms are responsible for generating organic acids and aromatic compounds in this food product $(3,4,9,10,18)$. Cheese production in Brazil involves milk fermentation by lactic acid bacteria, which are either deliberately added as starter cultures or are adventitious microbial populations, the growth of which is the result of the selective pressures encountered under the conditions used in the fermentation process $(5,20)$. Lactic acid bacteria occur naturally as part of the indigenous microbiota of raw milk, and the microbial diversity contributes to the large differences in organoleptic characteristics found in raw-milk cheeses (1).

Cachaça is the most important Brazilian distilled beverage $(13,26)$. During traditional cachaça production, lactic acid bacteria are considered contaminants in the fermentation process. These bacteria compete with yeasts for the sucrose found in the sugar cane juice, which then reduces the ethanol yield of fermentation (12). However, a precise correlation between bacterial contamination and reduced alcohol content during cachaça fermentation has not yet been shown (25).

The bacterial communities associated with sour cassava starch, cachaça and Minas cheese have been determined using cultivation techniques in combination with the molecular identification of isolates $(14,18,20,14)$. The aim of the present study was to examine the structure of the bacterial communities found in these traditional fermented products using direct DNA extraction, 16S rRNA gene amplification, cloning and sequencing.

\section{MATERIALS AND METHODS}

\section{Sample collection}

Sour cassava starch samples were collected from a factory in the city of Conceição dos Ouros, Minas Gerais, Brazil. The samples were collected 5,27 and 45 days after the fermentation process started, according to Lacerda et al. (18). Cachaça fermentation samples were collected from a traditional distillery in the city of Esmeraldas, Minas Gerais at 7,21 and 35 days after fermentation process started. Preparation procedures and sample collection for sour cassava starch and cachaça are described in Lacerda et al. (18) and Gomes et al. (13), respectively. After 7 and 60 days of maturation, Minas cheese samples were collected from a farm in the city of São Roque de Minas, Minas Gerais. This semi-hard Minas cheese, also known as Canastra cheese, is produced with raw milk and has been made at the farmhouse production level for the last 200 years using traditional procedures. Milk coagulation is a result of employing natural whey cultures as starter cultures (indigenous lactic acid bacteria) and commercial rennet. The natural microbiota present in the milk and in the environment is responsible for ripening (6). All samples were aseptically 
collected using sterile flasks and were stored at $-20^{\circ} \mathrm{C}$ until the DNA was extracted.

\section{DNA extraction, amplification and clone libraries}

DNA was extracted from $1 \mathrm{~g}$ of each sour cassava starch and cachaça fermentation sample, which was diluted in $9 \mathrm{~mL}$ sterile distilled water. Each 1-gram cheese sample was homogenized in $9 \mathrm{~mL}$ of $0.1 \%$ buffered peptone water. These suspensions were centrifuged at $15,000 \mathrm{rpm}$ for $10 \mathrm{~min}$, and DNA was extracted from the pellet using the procedure described by Lacerda et al. (18).

16S rRNA gene sequences were PCR amplified using the bacterial domain specific primers 27f (5'AGAGTTTGATCCT GGCTCAG3') and 1492r (5'GGTTACCTTGTTACGACTT3') (19). These primers amplify approximately 1,600 base pairs of the $16 \mathrm{~S}$ rRNA gene. PCR reactions were performed in a final reaction volume of $50 \mu \mathrm{L}$, containing 0.1-0.5 $\mu \mathrm{g}$ DNA, dNTPs

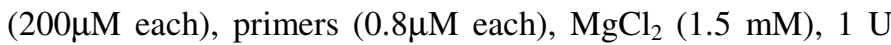
Taq DNA polymerase (Invitrogen) and the supplied buffer. The amplification conditions were as described in Morlon-Guyot et al. (22). The amplified fragments were purified using the Wizard system, ligated into the pGEM $^{\circledR}-\mathrm{T}$ Vector System II (Promega, Madison, USA) and transformed into competent $E$. coli (XL1-Blue) cells according to the manufacturer's instructions (Invitrogen). Blue/white screening on LuriaBertani (LB) agar containing ampicillin (Sigma), X-gal (Invitrogen) and isopropyl $\beta$-D-1-thiogalactopyranoside (IPTG, Promega) was used to randomly select approximately 30 white colonies for each sample. The clones were stored in freezing medium at $-80^{\circ} \mathrm{C}$.

\section{Sequencing of cloned DNA and identification}

Both strands of the cloned inserts were sequenced using the universal sequencing primers that correspond to the regions flanking the cloning site. Sequencing was performed using a DYEnamic Terminator Cycle Sequencing Kit in a MegaBACE $^{\mathrm{TM}} 1000$ automated sequencing system (Amersham
Biosciences, USA). These partial sequences were searched against sequenced deposited in GenBank using the advanced BLAST similarity search option (2). Partial sequences were approximately 600 base pairs long (range 350-940 bp). The nucleotide sequences and other related sequences were aligned using MEGA version 4. The 16S rRNA gene clone sequences that had a greater than $97 \%$ similarity to sequences deposited in GenBank were designated as belonging to the corresponding species (see accession numbers in Table 1).

\section{RESULTS AND DISCUSSION}

We sequenced 129 clones to identify the specific phylotypes of bacteria associated with the traditional processes used in sour cassava starch and Minas cheese fermentation and cachaça production. The overall structure of the bacterial communities found associated with these food products are summarized in Table 1.

Out of 45 clones examined from sour cassava starch fermentation, the most common species found after five days of fermentation were Leuconostoc mesenteroides, Leuconostoc pseudomesenteroides, Lactobacillus plantarum, Lactococcus lactis subsp. lactis, Leuconostoc citreum and Enterobacter sp. Leuconostoc citreum was the most prevalent species at the start of the fermentation process, representing $47.6 \%$ of the total clones analyzed. After 27 days of fermentation, two and five clones (GenBank accession number GQ999786 and GQ999788, respectively) were similar to uncultured bacterium clones, representing $43.8 \%$ of the bacterial community analyzed at this stage of the fermentation process. Enterobacter cloacae, Lactobacillus manihotivorans, Lc. lactis subsp. lactis, Lb. plantarum and Lactobacillus sp. were found at lower frequencies. After 45 days of fermentation, an uncultured bacterium clone (GenBank accession number GQ999786) was the most prevalent. This uncultured bacterium clone was distantly related (90\% identity) to some sequences deposited in GenBank, such as Enterobacter sp. (GenBank accession 
numbers GQ478379 and FJ646658). At this fermentation time, Lb. plantarum and Enterobacter sp. were found at a low frequency.

Ampe et al. (3) used denaturing gradient gel electrophoresis (DGGE) to show that the dominant bacteria involved in the spontaneous fermentation of sour cassava starch in Colombia were all lactic acid bacteria, mainly those closely related to Bifidobacterium minimum, Lc. lactis, Streptococcus sp., Enterococcus saccharolyticus and $L b$. plantarum.

Table 1. Most closely related bacterial species to the sour starch cassava, cachaça and cheese species based on BLASTn analysis.

\begin{tabular}{|c|c|c|c|c|c|c|c|}
\hline UFMGCB & $\begin{array}{c}\text { Most closely related } \\
\text { species/GenBank }\end{array}$ & & imes $^{\mathrm{a}}$ & Percent & bp & Identification & $\begin{array}{l}\text { GenBank } \\
\text { accession }\end{array}$ \\
\hline OF IVUCD & accession number & $\mathbf{I}$ & II III & similarity & analyzed & fuemintationit & number \\
\hline
\end{tabular}

\section{Sour cassava starch}

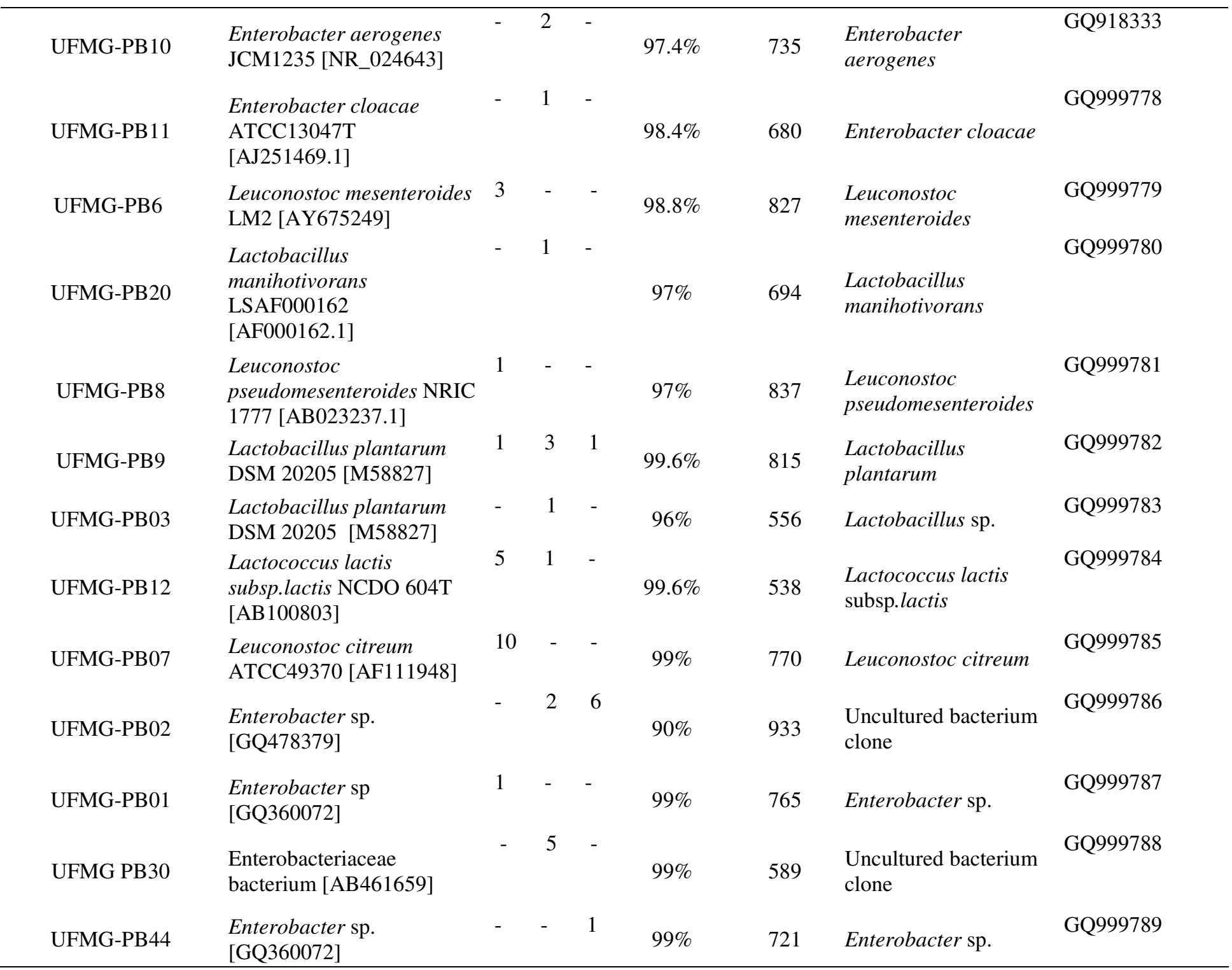


Cachaça

fermentation

\begin{tabular}{|c|c|c|c|c|c|c|c|}
\hline UFMG-CAB 11 & $\begin{array}{l}\text { Lactobacillus nagelii } \\
\text { ATCC } 700692 \text { [AB162131] }\end{array}$ & 1 & - & - & $90 \%$ & 541 & Lactobacillus sp. \\
\hline UFMG-CAB16 & $\begin{array}{l}\text { Lactobacillus paracasei } \\
\text { subsp. paracasei ATCC } \\
25302 \text { [D79212] }\end{array}$ & 3 & 1 & 1 & 100 & 812 & $\begin{array}{l}\text { Lactobacillus } \\
\text { paracasei subsp. } \\
\text { paracasei }\end{array}$ \\
\hline UFMG-CAB5 & $\begin{array}{l}\text { Lactobacillus nagelii } \\
\text { ATCC } 700692[\mathrm{AB} 162131]\end{array}$ & 9 & 1 & - & $99 \%$ & 800 & Lactobacillus nagelii \\
\hline UFMG-CAB6 & $\begin{array}{l}\text { Lactobacillus satsumensis } \\
\text { NRIC } 0604 \text { [AB154519] }\end{array}$ & - & 1 & - & $96 \%$ & 533 & Lactobacillus sp. \\
\hline UFMG-CAB12 & $\begin{array}{l}\text { Lactobacillus harbinensis } \\
\text { SBT10908 [AB196123.1] }\end{array}$ & - & 9 & 4 & $100 \%$ & 868 & $\begin{array}{l}\text { Lactobacillus } \\
\text { harbinensis }\end{array}$ \\
\hline UFMG-CAB9 & $\begin{array}{l}\text { Streptococcus salivarius } \\
\text { ATCC 25975(FJ154797.1) }\end{array}$ & - & - & 1 & $100 \%$ & 449 & $\begin{array}{l}\text { Streptococcus } \\
\text { salivarius }\end{array}$ \\
\hline UFMG-CAB 10 & $\begin{array}{l}\text { Lactobacillus buchneri } \\
\text { ATCC } 4005 \text { [AB205055] }\end{array}$ & - & - & 11 & $99 \%$ & 781 & $\begin{array}{l}\text { Lactobacillus } \\
\text { buchneri }\end{array}$ \\
\hline UFMG-CAB 14 & $\begin{array}{l}\text { Lactobacillus acetolerans } \\
\text { JCM } 9904 \text { [AB289008] }\end{array}$ & - & - & 1 & $99 \%$ & 763 & $\begin{array}{l}\text { Lactobacillus } \\
\text { acetolerans }\end{array}$ \\
\hline UFMG-CAB17 & $\begin{array}{l}\text { Lactobacillus plantarum } \\
\text { DSM } 20205 \text { [M58827] }\end{array}$ & - & - & 1 & $98.8 \%$ & 421 & $\begin{array}{l}\text { Lactobacillus } \\
\text { plantarum }\end{array}$ \\
\hline
\end{tabular}

GQ999790

GQ999791

GQ999792

GQ999793

GQ999794

GQ999795

GQ999796

GQ999797

GQ999798

Minas cheese

\begin{tabular}{|c|c|c|c|c|c|c|}
\hline UFMG-QB5 & $\begin{array}{l}\text { Lactobacillus plantarum } \\
\text { DSM 20205 [M58827] }\end{array}$ & 1 & 4 & $99.5 \%$ & 390 & $\begin{array}{l}\text { Lactobacillus } \\
\text { plantarum }\end{array}$ \\
\hline UFMG-QB6 & $\begin{array}{l}\text { Lactococcus lactis NCDO } \\
604 \mathrm{~T} \text { [AB100803] }\end{array}$ & 9 & 4 & $100 \%$ & 499 & Lactococcus lactis \\
\hline UFMG-QB3 & $\begin{array}{l}\text { Lactobacillus brevis ATCC } \\
14869 \text { [M58810.1] }\end{array}$ & - & 1 & $99 \%$ & 700 & Lactobacillus brevis \\
\hline UFMG-QB16 & $\begin{array}{l}\text { Sphingomonas sp. Clone } \\
\text { FI012 [AY349411] }\end{array}$ & - & 2 & $99 \%$ & 614 & Sphingomonas sp. \\
\hline UFMG-QB55 & $\begin{array}{l}\text { Lactobacillus arizonensis } \\
\text { NRRLB14768 [AJ965482] }\end{array}$ & - & 7 & $99.8 \%$ & 496 & $\begin{array}{l}\text { Lactobacillus } \\
\text { arizonensis }\end{array}$ \\
\hline UFMG-QB26 & $\begin{array}{l}\text { Streptococcus salivarius } \\
\text { ATCC 7073_(AY188352.1) }\end{array}$ & 1 & 10 & $99.6 \%$ & 720 & $\begin{array}{l}\text { Streptococcus } \\
\text { salivarius }\end{array}$ \\
\hline JFMG-QB20 & $\begin{array}{l}\text { Uncultured Streptococcus } \\
\text { sp. clone SC002B48 } \\
\text { [AY807774.1] }\end{array}$ & - & 1 & $99.6 \%$ & 721 & $\begin{array}{l}\text { Uncultured clone } \\
\text { Streptococcus sp. } \\
\text { clone }\end{array}$ \\
\hline
\end{tabular}

GQ999799

GQ999800

GQ999801

GQ999802

GQ999803

GQ999804

GQ999805

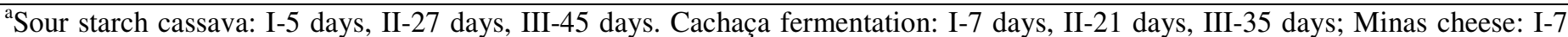
days, II-60 days. 
The presence of $L b$. manihotivorans was only detected when 16S rRNA genes were hybridized with phylogenetic probes. Using culture-dependent methods, Lacerda et al. (18) showed that Lb. plantarum and Lactobacillus fermentum were the species most frequently associated with sour cassava starch fermentation at two factories in the state of Minas Gerais. However, the results obtained using clone library sequence analysis showed that the prevalence of lactic acid bacteria was limited to the first five days of fermentation, and a lower prevalence of these bacteria was detected at later time points. Lb. plantarum was detected in the three fermentation samples assayed but at low frequencies. Uncultured bacterium clones were prevalent after 27 and 45 days of fermentation. Figueroa et al. (10) suggested that the traditional sour cassava starch fermentation process is characterized by a succession of microbial populations. Ampe et al. (3) suggested that this succession could be determined by the varying sensitivities of microorganisms to the acidic conditions that develop during the fermentation process. Our results show that unculturable bacteria were found at a high frequency during the middle and at the end of the sour cassava fermentation process. These microorganisms may potentially play an important role in the fermentation process that should be examined further.

Most of the clones obtained during the fermentation of cachaça corresponded to lactic acid bacteria belonging to the genus Lactobacillus. The bacterial communities present in this fermentation process are very similar regardless of the raw material used and are characterized by the presence of lactic acid species, especially those from the genera Lactobacillus, Leuconostoc, Weissella and Lactococcus (14). Many species from these genera are characteristically resistant to low $\mathrm{pH}$ and high alcohol concentrations, which explains their presence and wide distribution in different fermentation processes, including both alcoholic and lactic fermentation processes (15). After 7 days of fermentation, the most prevalent species was $L b$. nagelli, representing $76.9 \%$ of the total clones analyzed. The other clones were Lactobacillus sp. and Lactobacillus paracasei subsp. paracasei. After 21 days, Lb. harbinensis was the most prevalent species, representing $75 \%$ of the total clones. Lb. paracasei subsp. paracasei, Lb. nagelli and Lb. satsumensis were found at lower frequencies. After 35 days of fermentation, Lb. buchneri was the most prevalent species, representing $57.9 \%$ of the clones analyzed, followed by $L b$. harbinensis (21\%). Lb. paracasei subsp. paracasei, Streptococcus salivarius, Lb. acetolerans and Lb. plantarum were also found at lower frequencies. Leuconostoc mesenteroides, Lb. plantarum, and Lb. brevis were described as contaminants of the cachaça fermentation vats $(23,27)$. Carvalho-Netto et al. (6) also characterized the bacterial community during cachaça production in the state of São Paulo using partial 16S rRNA gene sequencing. Their analysis included 587 sequences and revealed the presence of 170 operational taxonomic units. The genus Lactobacillus was the most predominant, accounting for approximately $66 \%$ of the sequences, and Lb. hilgardii and Lb. plantarum were the species most frequently found. Other species were found at lower frequencies, such as Curtobacterium flaccumfaciens, Lactobacillus casei, Leuconostoc mesenteroides and Ln. citreum. Gomes et al. (14) identified populations of culturable lactic acid bacteria involved in cachaça fermentation using both physiological and molecular methods. A high frequency of lactic acid bacteria was found during the entire fermentation process, and the species Lb. plantarum and Lb. casei were the most prevalent in the vats. These differences may be related to the different approaches used and the regional differences in the composition of the lactic acid bacterial community; Carvalho-Netto et al. (6) worked with fermentations from the state of São Paulo, whereas our work was performed with distilleries from the state of Minas Gerais.

The characterization of the bacterial communities involved in the production of cachaça using culture-dependent and culture-independent techniques shows the prevalence of a variety of Lactobacillus species during the fermentation process. Lactobacillus plantarum was the only common 
species found during cachaça fermentation using both techniques. Although lactic acid bacteria are considered to be contaminants in cachaça fermentation, it is important to understand the influence these microorganisms have on the cachaça fermentation process (14). Lactic acid bacteria ferment glucose and produce lactic acid as their main metabolic byproduct, thus reducing the yield of alcohol. The microbial community present during fermentation is also responsible for producing secondary compounds that determine the flavor of the beverage. The presence of certain concentrations of bacteria during fermentation is not considered a contaminating factor but rather an essential component of the final quality of the beverage (6). However, there is little information available regarding the composition and concentration of these microorganisms during cachaça production. Therefore, a better understanding of the relationship between the microorganisms involved in the fermentation process and the final chemical quality of the beverage is needed.

We obtained 40 clones from cheese samples after 7 and 60 days of ripening. After 7 days of ripening, 9 clones of Lc. lactis and 1 clone of both $L b$. plantarum and $S$. salivarius were found. After 60 days of ripening, S. salivarius was the most prevalent, representing $34.5 \%$ of the clones obtained. Lactobacillus arizonensis was the second most prevalent species, representing $24.1 \%$ of the total clones. Lactobacillus plantarum and Lc. lactis were also isolated at this ripening time with other bacteria, such as Lactobacillus brevis, Sphingomonas sp. and an uncultured Streptococcus sp. Lactic acid bacteria found during cheese ripening are collectively referred to as non-starter lactic acid bacteria, and they are considered to be the species involved mainly in flavor development. The composition of these bacterial species varies with the method used in milk processing and the age of the cheese (21). The presence of lactic acid bacteria during cheese maturation has been described in several reports $(5,11,21,24)$. Duthoit et al. (8) used clone libraries and 16S rRNA gene sequencing to show that the lactic acid bacteria Lc. lactis, Lb. plantarum, S. termophilus, Enterococcus faecium, Ln. mesenteroides, Ln. pseudomesenteoides and Lb. pentosus were the most predominant during the manufacturing and ripening of Salers, an artisanal cheese produced in France. The first two species were also found during the ripening of Canastra Minas cheese in our study.

The succession of the bacterial populations observed using an analysis of a $16 \mathrm{~S}$ rRNA gene clone library showed that the fermentation of sour cassava starch, cachaça and Minas cheese is mediated by complex microbial ecosystems, which include both lactic acid and uncultured bacteria. The acidic conditions found during these fermentation processes may be the most important factor in determining the prevalence of the different bacterial species during traditional fermentation. Lactic acid bacteria were the most prevalent species during the fermentation processes for cachaça and Canastra Minas cheese production. Unculturable bacteria predominated during the middle and at the end of sour starch cassava fermentation. These unculturable bacteria may play an important role in the fermentation process, and more studies are necessary to understand the contribution these microorganisms make to the quality of this product.

\section{ACKNOWLEDGEMENTS}

This work was funded by the Conselho Nacional de Desenvolvimento Científico e Tecnológico (CNPq) and Fundação de Amparo à Pesquisa do Estado de Minas Gerais (FAPEMIG).

\section{REFERENCES}

1. Abriouel, H.; Platero, A.M.; Maqueda, M.; Valdivia, E.; Bueno, M.M. (2008). Biodiversity of the microbial community in a Spanish farmhouse cheese as revealed by culture-dependent and culture-independent methods. Int. J. Food Microbiol.127, 200-208.

2. Altschul, S. F.; Madden, T. L.; Schaffer, A. A.; Zhang, J.; Zhang, Z.; Miller, W.; Lipman, D. J. (1997). Gapped BLAST and PSI-BLAST: a 
new generation of protein database search programs. Nucleic Acid Res. 25, 3389-3402.

3. Ampe, F.; Sirvent, A.; Zakhia, N. (2001). Dynamics of the microbial community responsible for traditional sour cassava starch fermentation studied by denaturing gradient gel electrophoresis and quantitative rRNA hybridization. Int. J. Food Microbiol. 65, 45-54.

4. ben Omar, N.; Ampe, F.; Raimbault, M.; Guyot, J.-P.; Tailliez, P. (2000). Molecular diversity of lactic acid bacteria from cassava sour starch (Colombia). Syst. Appl. Microbiol. 23, 285-291.

5. Borelli, B.M.; Ferreira, E.G.; Lacerda, I.C.A.; Franco, G. R.; Rosa, C. A. (2006). Yeast populations associated with the artisanal cheese produced in the region of Serra da Canastra, Brazil. World J. Microbiol. Biotechnol. 22, 1115-1119.

6. Carvalho-Netto, O. V.; Rosa, D. D.; Camargo, L. E. A. (2008). Identification of contaminat bacteria in cachaça yeast by $16 \mathrm{~S}$ RDNA gene sequencing. Sci. Agric. 65, 508-515.

7. Cereda M. P. (1987) Tecnologia e qualidade do polvilho azedo. Inf. Agrop. 13, 63-68.

8. Duthoit, F.; Godon, J.J.; Montel, M. C. (2003). Bacterial community dynamics during production of registered designation of origin salers cheese as evaluated by $16 \mathrm{~S}$ rRNA gene single-strand conformation polymorphism analysis. Appl. Environ. Microbiol. 69, 3840-3848.

9. Figueroa, C.; Davila, A. M.; Pourquié, J. (1995). Lactic acid bacteria of the sour cassava starch fermentation. Lett. Appl. Microbiol. 21, 126-130.

10. Figueroa, C.; Davila, A. M.; Pourquié, J. (1997). Original properties of ropy strains of Lactobacillus plantarum isolated from the sour cassava starch fermentation. J. Appl. Microbiol. 82, 68-72.

11. Gala, E.; Landi, S.;Solieri, L.; Nocetti, M.; Pulvirenti, A.; Giudici, P. (2008). Diversity of lactic acid bacteria population in ripened Parmigiano Reggiano cheese. Int. J. Food. Microbiol. 125, 347-351.

12. Gallo, C. R. (1992). Identificação de bactérias contaminantes da fermentação alcoólica. $S T A B$ 4/5, 30-34.

13. Gomes, F.C.O.; Silva, C.L.C.; Marini, M.M.; Oliveira, E.S.; Rosa, C.A (2007). Use of selected indigenous Saccharomyces cerevisiae strains for the production of the traditional cachaça in Brazil. J. Appl. Microbiol. $103,2438-2447$.

14. Gomes, F. C. O.; Silva, C. L. C.; Vianna, C. R.; Lacerda, I. C. A; Borelli, B. M.; Nunes, A. C.; Franco, G. R.; Mourão, M.; Rosa, C. A. (2010). Identification of lactic acid bacteria associated with traditional cachaça fermentations in Brazil. Braz. J. Microbiol. 41, 486-492.

15. Huhtamella, S.; Leinonen, M.; Nieminen, T.; Fahnert, B.; Myllykoski, L.; Breitenstein, A.; Neubauer P. RNA-based sandwich hybridization method for detection of lactic acid bacteria in brewery samples. $J$. Microbiol. Methods 68, 543-553, 2007.

16. Jany, J.L.; Barbier, G. (2008). Culture-independent methods for identifying microbial communities in cheese. Food Microbiol. 25, 839-
848.

17. Justé, A.; Thomma, B.P.H.J.; Lievens, B. (2008). Recent advances in molecular techniques to study microbial communities in food-associated matrices and processes. Food Microbiol. 25, 745-761.

18. Lacerda, I.C.A.; Miranda, R.L.; Borelli, B.M.; Nunes, A.C.; Nardi, R.M.D.; Lachance, M.A.; Rosa, C.A. (2005). Lactic acid bacteria and yeast associated with spontaneous fermentations during the production of sour cassava starch in Brazil. Int. J. Food Microbiol. 105, 213-219.

19. Lane, D.J. (1991). 16S-23S rRNA sequencing. In: Stackebrandit, R., Goodfelouw, M. (eds). Nucleic acid techniques in bacterial systematics. Wiley, New York, USA, p. 117-175.

20. Lima, C.D.C.; Cerqueira, M.M.O.P.; Ferreira, E.G.; Faria Jr.; C.L.L.; Nelson, D.L.; Carmo, L.S.; Rosa, C.A. (2008). Microbiological, physical-chemical and sensory evaluation of a traditional Brasilian cheese during the ripening progress. World J. Microbiol. Biotechnol. 24, 2389-2395.

21. McSweeney, P.L.H.; Ottogalli, G.; Fox, P.F. (2004). Diversity of cheese varieties: an overview. In: Fox, P.H.; Mc Sweeney, P.L.H.; Cogan, T.; Guinee, T. (Eds). Cheese: Chemistry, Physics and Microbiology, Elsevier Academic Press, San Diego, USA, p.1-22.

22. Morlon- Guyot, M. J.; Guyot, J. P.; Pot, B.; Haut, J.; Raimbault, M. (1998). Lactobacillus manihotivorans sp. nov., a new starch-hydrolysin lactic acid bacterium isolated during cassava sour starch fermentation. Int. J. Syst. Bacteriol.48, 1101-1109.

23. Oliva-neto, P.; Yokoya, F. (1994). Evaluation of bacterial contamination in a fed-batch alcoholic fermentation process. World J. Microbiol. Biotechnol. 10, 697- 699.

24. Randazzo, C.L.; Torriani, S.; Akkermans, A.D.L.; Vos, W.M.; Vaughan, E.E. (2002). Diversity, dynamics, and activity of bacterial communities during production of an artisanal Sicilian cheese as evaluated by $16 \mathrm{~S}$ rRNA analysis. Appl. Environ.Microbiol. 68, 1882-1892.

25. Rosa, C.A.; Soares, A.M.; Faria, J.B. Cachaça production. (2009). In: Ingledew, W.M.; Kelsall, D.R.; Austin, G.D.; Kluhspies, C. (eds). The Alcohol TextBook: Nottingham University Press, Nottingham, UK, p. 481-490.

26. Silva, C.L.C.; Vianna, C. R.; Cadete, R. M.; Santos, R. O.; Gomes, F. C. O.; Oliveira, E. S.; Rosa, C. A. (2009). Selection, growth, and chemosensory evaluation of flocculent starter culture strains of Saccharomyces cerevisiae in the large-scale production of traditional Brazilian cachaça. Int. J. Food Microbiol.131, 203-210.

27. Schwan, R.F.; Mendonça, A.T.; Silva-Júnior, J.J.; Rodrigues, V.; Wheals, A.E. (2001) Microbiology and physiology of cachaça (aguardente) fermentations. Antonie van Leeuwenhoek 79, 89-96.

28. Yang, C.H.; Crowley, D.E.; Borneman, J.; Keen, N.T. (2001). Microbial phyllosphere populations are more complex than previously realized. Proc. Natl. Acad. Sci. USA 98, 3889-3894. 